\title{
Clostridium Cluster IV
}

National Cancer Institute

\section{Source}

National Cancer Institute. Clostridium Cluster IV. NCI Thesaurus. Code C129412.

A group of at least 8 bacterial species, four in the Clostridium genus and 4 that are classified outside the Clostridium genus. This cluster is based on comparative sequence analysis of their $16 \mathrm{~S}$ ribosomal RNA gene sequences. These species are commensal in humans. 